\title{
ANNOUNCEMENT
}

\author{
Annual Meeting
}

\section{Canadian Congress of}

\author{
Neurological Sciences,
}

\section{Winnipeg - June 23rd - 26th, 1976}

\author{
Details from \\ Dr. F. Andermann \\ 1610 Pine Ave. W. \\ Montreal, P.Q. H3G 1B4 \\ or \\ Dr. H. W. K. Barr \\ 211 - 111 Waterloo St. \\ London, Ont. N6B $2 \mathrm{M} 4$.
}

